\title{
Regional workshop to use the findings from operations research to increase the access, quality and integration of contraceptive services in Latin America and the Caribbean
}

M. Estela Rivero-Fuentes

Population Council

Antonieta Martin

Population Council

Follow this and additional works at: https://knowledgecommons.popcouncil.org/departments_sbsr-rh

Part of the Demography, Population, and Ecology Commons, International Public Health Commons, Public Health Education and Promotion Commons, and the Women's Health Commons

How does access to this work benefit you? Let us know!

\section{Recommended Citation}

Rivero-Fuentes, M. Estela and Antonieta Martin. 2008. "Regional workshop to use the findings from operations research to increase the access, quality and integration of contraceptive services in Latin America and the Caribbean," FRONTIERS Final Report. Washington, DC: Population Council. 


\section{Regional Workshop to Use the Findings from Operations Research to Increase the Access, Quality and Integration of Contraceptive Services in Latin America and the Caribbean}

\section{Frontiers in Reproductive Health (FRONTIERS), Population Council M. Estela Rivero-Fuentes \\ Antonieta Martin}

April 2008

This study was possible through the generous support of the people of the United States through the United States Agency for International Development (USAID), under the terms of Cooperative Agreement No. HRNA-00-98-00012-00 and In-house project 5800 53117. The contents are the responsibility of the FRONTIERS Program and do not necessarily reflect the points of view of USAID or the United States Government. 


\section{EXECUTIVE SUMMARY}

In October 2007, the Frontiers in Reproductive Health Program (FRONTIERS) held a three-day regional workshop in La Antigua, Guatemala, to disseminate results of its operations research projects. The workshop was attended by 60 participants from 11 countries: Bolivia, the Dominican Republic, Ecuador, El Salvador, Guatemala, Haiti, Honduras, Mexico, Nicaragua, Peru and the United States. Participants included health providers, program managers, nongovernmental organization (NGO) directors, bilateral-agreements country representatives, and directors of professional organizations, the list of participants was composed of delegates from Ministries of Health (MOH), Social Security Institutes (SSI), USAID missions, international agencies, and non-governmental organizations (NGOs).

During the workshop, participants received contraceptive technology updates, and learned about effective strategies tested by FRONTIERS to increase access to the IUD and vasectomy, integration of family planning with postpartum, postabortion and PMTCT. Featured were the Balanced Counseling Strategy (BCS), and Systematic Screening. Researchers discussed study results; program managers explained how they were used, and practitioners talked about implementing the interventions. This combination of perspectives successfully transmitted the message that the interventions were not difficult to apply, could have a great impact, and, as one participant wrote on the evaluation form, that "small changes could lead to great results".

Workshop participants also received materials developed by FRONTIERS and other institutions to help integration efforts. The materials distributed included:

a) Three CDs. The first was prepared specially for the meeting, containing all the Spanishlanguage versions of FRONTIERS final reports, operations research summaries, manuals, and job-aids, as well as WHO's medical eligibility criteria for contraceptive use (MEC). The CD also included a compilation of scientific articles and job-aids on postpartum contraception; and the IUD toolkit. The second CD was "Improving Reproductive Health Services. FRONTIERS Operations Research. 1998-2005," and the third, the "Frontiers in Reproductive Health Electronic Library 1990-1999."

b) The Spanish translation of Family Health International's (FHI) "Frequently Asked Questions on Contraception."

c) The Spanish version of the systematic screening manual and examples of the algorithm used in Latin American countries.

d) The Spanish version of the Balanced Counseling Strategy including cards, brochures and algorithm.

Participants prepared plans to put lessons learned at the workshop into practice. Seven countries prepared action plans (Bolivia, the Dominican Republic, Ecuador, El Salvador, Guatemala, Honduras and Nicaragua). Others proposed organizing an informal electronic forum to continue discussing the topics covered at the workshop. Four countries said they would attempt to adapt the BCS or the systematic screening technique to their local context, and three proposed to 
strengthen the integration of family planning and prevention of mother to child transmission of HIV services.

The final workshop evaluations, returned by 23 participants, showed that they found the workshop very useful for their work. When asked what they liked the most, $57 \%$ mentioned the balanced counseling strategy and 52\% mentioned the exchange of experiences. After the workshop ended, Population Council created an URL that displays the workshop presentations and all the materials distributed. 


\section{TABLE OF CONTENTS}

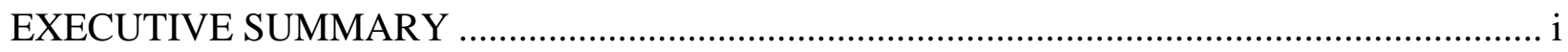

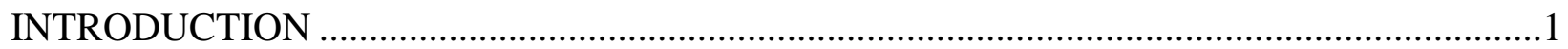

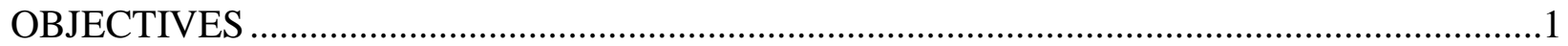

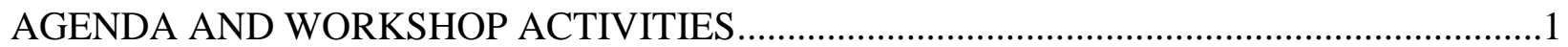

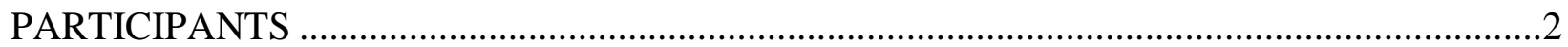

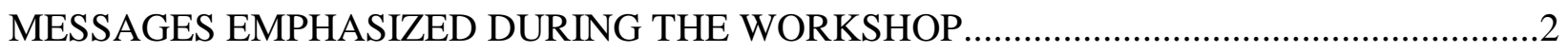

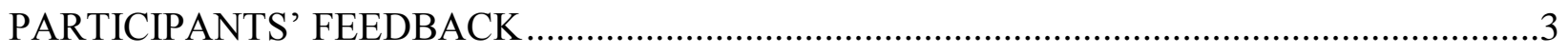

Lessons learned ................................................................................................................. 4

PERCEIVED OBSTACLES TO THE IMPLEMENTATION OF THE STRATEGIES

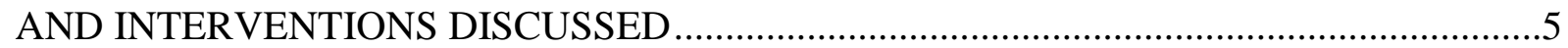

PLANS TO IMPLEMENT LESSONS LEARNED AT THE WORKSHOP ...................................6

APPENDIX 1: FRONTIERS PROJECTS REFERRED TO DURING THE WORKSHOP,

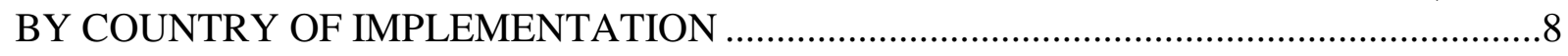

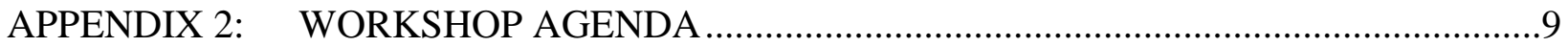

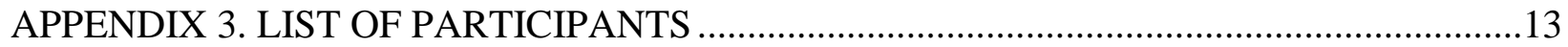

APPENDIX 4: FEEDBACK QUESTIONNAIRES AND WORKING GROUP

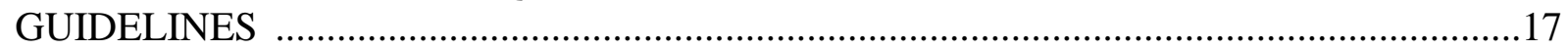

\section{LIST OF TABLES}

TABLE 1: TOP-THREE TOPICS PERCEIVED AS THE MOST USEFUL, BY WORKSHOP DAY

TABLE 2: MOST IMPORTANT LESSONS FROM COUNTRY GROUP WORK SESSIONS 


\section{INTRODUCTION}

In Latin America, the Population Council's Frontiers in Reproductive Health (FRONTIERS) program, funded by USAID, continued to support a program of operations research initiated by the Investigación Operativa en Planificación Familiar y Atención Materno-Infantil para América Latina y el Caribe (INOPAL) I, II and III programs, all of which had been funded by USAID and implemented by the Population Council between 1984 and 1998. The strategies and results presented during the workshop drew primarily from FRONTIERS and INOPAL projects in the region, but relevant results from Sub-Saharan Africa and Asia and the Middle East were also presented. Altogether, the presentations summarized 23 FRONTIERS projects (see Appendix 1) and the subsequent experience of program managers, and health providers in scaling-up and making the interventions sustainable.

The workshop emphasized integration of family planning with other health services and the need for systematic screening as an entry point for identifying and meeting various FP/RH needs. Presentations were also made about strategies to integrate family planning and postpartum, postabortion, and PMTCT services. Strategies for the introduction of vasectomy, the Balanced Counseling Strategy, and increasing IUD use were also discussed.

\section{OBJECTIVES}

- To contribute to the strengthening of family planning programs in the region through the communication of lessons learned and materials developed.

- To raise awareness of FRONTIERS-supported projects in the design, testing and implementation of innovative strategies.

- To give an overview of contraceptive methods available in the region, review WHO eligibility criteria, and the status of family planning programs.

\section{AGENDA AND WORKSHOP ACTIVITIES}

On the first day, participants heard about the current situation of family planning programs in Latin America and the Caribbean, strategies to increase access to the IUD in Guatemala and Honduras, and the introduction of no-scalpel vasectomy, in public hospitals in Guatemala.

The second day covered minilaparotomy, emergency contraception, natural family planning and strategies for integrating family planning and postpartum, postabortion and PMTCT services.

During the third day, participants listened to presentations on Systematic Screening and the Balanced Counseling Strategy, followed by break-out groups in which they learned how to apply the techniques. Before the workshop's closing ceremony, groups of participants from the same country identified the themes and lessons that were most useful for them, and each suggested three concrete actions they would take to implement lessons learned into practice. The workshop agenda is included as Appendix 2. 


\section{PARTICIPANTS}

A total of 60 individuals from reproductive health organizations in Latin America and the Caribbean participated in the workshop. USAID missions and Ministries of Health in Bolivia, the Dominican Republic, Ecuador, El Salvador, Guatemala, Haiti, Honduras, Nicaragua and Peru helped identify participants from relevant institutions who had the potential to use the strategies discussed in the workshop. The list of participants, presented in Appendix 3, shows that the participants represented ministries of health, national social security institutes, non-governmental organizations, and international agencies.

Presenters were selected for their involvement in the operations research studies presented in the workshop and expertise in at least one of the workshop topics. Presenters were from:

- Asociación Guatemalteca de Mujeres Médicas (AGMM) in Guatemala

- Asociación Pro-Salud Preventiva para la Mujer Vivamos Mejor (APROVIME) in Guatemala

- Population Council offices in Bolivia, Mexico and New York

- Ipas in North Carolina

- Instituto Peruano de Paternidad Responsable (INPPARES), Perú

- Ministries of Health in the Dominican Republic, Honduras, Guatemala, and Mexico.

- UNDP in Guatemala

- EngenderHealth in Honduras

- USAID Mission in Haiti.

\section{MESSAGES EMPHASIZED DURING THE WORKSHOP}

The texts of the presentations are included on the workshop CD. Also, a website will be created to make these materials and the presentations available to the open public.

Current Situation of Family Planning Programs in Latin America and the Caribbean

- John Townsend, Population Council, USA

International Contraceptive Access (ICA) Foundation and the Levonogerstrel Intra-Uterine System (LNG IUS)

- John Townsend, Population Council, USA and Klaus Brill, Bayer Schering Pharma AG

Family Planning in Guatemala's Ministry of Health

- Carlos Morales, MSPAS, Guatemala

Expanding Access to the IUD in Guatemala and Honduras

- Carlos Morales, Edwin Montúfar, Josefina Ajpop y Carlos Fernando Alvarado, MSPAS, Guatemala, and Alba Lidia Sánchez, EngenderHealth, Honduras 
Voluntary No-Scalpel Vasectomy (VNSV): New Techniques for the Procedure and Strategies to Promote its Use and Increase its Access

- Salvador Estévez, Secretaría de Salud, México, Jorge Solórzano, PNUD, Guatemala and Otto René Alvarado, MSPAS, Guatemala

Postpartum Minilaparatomy in a Hospital in Honduras

- José Manuel Espinal, Secretaría de Salud, Honduras

Standard-days (Cycle-Beads) Method in Guatemala

- Lidia de Mazariegos, APROVIME, Guatemala

Contraception from a Rights Perspective, with a Focus on Emergency Contraception

- Daniel Aspilcueta, INPPARES, Peru

Postabortion Contraception: Review of OR Results in LAC

- Deborah Billings, IPAS, USA

OR on Postpartum Contraception in LAC: A Review of Results

- Ricardo Vernon, Population Council, Mexico

Integration of Contraception Services in PMTCT Programs

- Estela Rivero, (Population Council, Mexico), Osvaldo Lorenzo, (SESPAS, Dominican Republic), Yolani Valle, (Secretaria de Salud, Honduras) and Pierre Mercier, USAID, Haiti

Systematic Screening: Evidence of its Effects from OR

- Ricardo Vernon, Population Council, Mexico and Patricia Riveros, Population Council, Bolivia

Quality of Care: The Balanced Counseling Strategy (BCS) and its effects

- Toni Martin, Population Council, Mexico and Rossana Cifuentes, AGMM, Guatemala

\section{PARTICIPANTS' FEEDBACK}

Participants had several opportunities to give feedback about what they thought were the workshop's most important lessons, and overcoming potential barriers to implementation of the lessons in their own organizations. Participants filled out a questionnaire describing what was, in their opinion, the most important lesson of the day.

They were also asked to write a quick assessment of the extent to which services were integrated in their own institutions, which areas of integration were a priority for them, and which interventions presented during the workshop could be implemented in their institutions. On the last day of the workshop, participants filled out a final evaluation form (see Appendix 4). 


\section{Usefulness of the workshop and most relevant topics}

Twenty three participants completed the final evaluation questionnaire; 19 found the workshop very useful and 4 participants found it useful. When asked which of the topics had been most useful, $57 \%$ mentioned the BCS. Other topics mentioned as being useful were no-scalpel vasectomy, the contraceptive updates, and the integration of family planning and postpartum, postabortion and PMTCT services (see table 1).

Table 1: Top-three topics perceived as the most useful, by workshop day

\begin{tabular}{|l|l|l|l|}
\hline Range & Day $\mathbf{1}^{\text {a }}$ & Day 2 $^{\mathbf{b}}$ & $\begin{array}{l}\text { Day 3 - final } \\
\text { evaluation }\end{array}$ \\
\hline $\mathbf{1}^{\text {st }}$ & No-scalpel vasectomy (73\%) & $\begin{array}{l}\text { Integration of FP and PAC } \\
(66 \%) \text { and PMTCT }(66 \%)\end{array}$ & BCS (57\%) \\
\hline $\mathbf{2}^{\text {nd }}$ & $\begin{array}{l}\text { Contraceptive updates } \\
(59 \%)\end{array}$ & $\begin{array}{l}\text { Postpartum contraception } \\
(34 \%)\end{array}$ & $\begin{array}{l}\text { No-scalpel vasectomy } \\
(22 \%)\end{array}$ \\
\hline $\mathbf{3}^{\text {rd }}$ & $\begin{array}{l}\text { Increasing access to the } \\
\text { IUD (51\%) }\end{array}$ & $\begin{array}{l}\text { Systematic screening } \\
(17 \%)\end{array}$ \\
\hline
\end{tabular}

a) Percentages based 41 responses. Multiple responses were accepted.

b) Percentages based 23 responses. Multiple responses were accepted.

c) Percentages based 23 responses. Multiple responses were accepted.

When asked what they liked best about the dynamics of the workshop, the most common replies were that it presented practical strategies to help improve the integration of services, and the opportunity to exchange experiences (mentioned by $52 \%$ ). The exchange was credited with helping participants detect shortcomings in their own programs:

"This workshop has helped us to identify the strengths and weaknesses in our countries. It is also a motivation to revisit successful experiences and to reinforce the monitoring and evaluation of our interventions."

When asked what they disliked about the workshop, most referred to the lack of time for more discussion (10 of the 14 participants). Other participants mentioned that they had missed having group-exercises:

"Everything was OK, but sometimes there was not enough time for discussion. Also, not doing the group exercises limited the exchange of experiences."

\section{Lessons learned}

At the end of the first and second day, participants summarized in one sentence the most important lesson of the day. The most common messages include:

\section{A) Integration of services requires team work:}

"Program sustainability needs alliances, either between organizations or with civil society."

"Teamwork: from the doorman to the Director. Everyone should be involved in improving the promotion and acceptance of vasectomy." 
B) Small changes can lead to great results.

"Everything is possible with will and training. No major resources are needed to implement interventions that benefit the majority."

C) Many opportunities are missed for the provision of family planning services "All occasions are good to offer clients all reproductive health services."

"We should take action and leadership in the decisions to integrate services. Commitment should exist at all levels."

"Health providers' willingness is central to all actions."

D) It is important to learn from experiences and evidence-based practices

"Even when we know a lot about family planning, there is always the opportunity to learn from others."

"If we share our experiences, we grow together."

\section{PERCEIVED OBSTACLES TO THE IMPLEMENTATION OF THE STRATEGIES AND INTERVENTIONS DISCUSSED}

In the recap exercises at the end of the first and second days, participants listed the barriers they thought would be faced if the interventions discussed were to be replicated in their institutions. The barriers mentioned for increasing access to the IUD, vasectomy, and integration of family planning and postpartum, postabortion and PMTCT services included:

1) Lack of institutional support. Half of the participants who answered the feedback questionnaires mentioned that efforts to improve access to the IUD and vasectomies and to increase the integration of family planning and other services depended heavily on support from the $\mathrm{MOH}$, which was not always existent. Others also mentioned that organizations were not interested in forging alliances.

2) Negative staff attitudes and lack of training, particularly for IUD insertions, vasectomies, and the integration with PMTCT programs. Participants also mentioned that in some instances trained staff do not feel confident enough to insert IUDs or perform vasectomies.

3) Economic constraints, such as lack of funds and method stock outs.

4) Cultural perceptions, myths and fears relating the IUD and the vasectomy.

5) Lack of funding coordination funding among programs; this is particularly relevant in the case of family planning and PMTCT programs.

6) The influence of the church and other conservative groups. 


\section{PLANS TO IMPLEMENT LESSONS LEARNED AT THE WORKSHOP}

At the end of the workshop, participants formed country-specific working groups to identify the three lessons or topics that they considered most relevant for their country, and to define three actions that would help implement these lessons (the guiding handouts are attached at the end of appendix 4), Representatives from seven countries completed this exercise.

Table 2 summarizes the lessons that countries found most important. With the exception of Ecuador, all countries mentioned BCS and systematic screening. Other topics considered to be of special relevance by were the no-scalpel vasectomy and the integration of family planning and PMTCT.

Table 2: $\quad$ Most important lessons from country group work sessions

\begin{tabular}{|l|c|c|c|c|c|c|c|}
\hline \multirow{2}{*}{ Lesson } & \multicolumn{7}{c|}{ Country } \\
\cline { 2 - 8 } & Bolivia & DR & Ecuador & $\begin{array}{c}\text { El } \\
\text { Salvador }\end{array}$ & Guatemala & Honduras & Nicaragua \\
\hline BCS & $\square$ & $\square$ & $\square$ & $\square$ & $\square$ & $\square$ & $\square$ \\
\hline $\begin{array}{l}\text { Systematic } \\
\text { screening }\end{array}$ & $\square$ & $\square$ & & $\square$ & $\square$ & $\square$ & $\square$ \\
\hline $\begin{array}{l}\text { No-scalpel } \\
\text { vasectomy }\end{array}$ & $\square$ & $\square$ & $\square$ & $\square$ & & & \\
\hline $\begin{array}{l}\text { FP/PMTCT } \\
\text { integration }\end{array}$ & & & & $\square$ & & & $\square$ \\
\hline $\begin{array}{l}\text { Contraceptive } \\
\text { methodology } \\
\text { updates }\end{array}$ & & & $\square$ & & & & \\
\hline $\begin{array}{l}\text { Strategies to } \\
\text { increase access } \\
\text { to the IUD }\end{array}$ & & & & & & & \\
\hline $\begin{array}{l}\text { Strategies to } \\
\text { increase access } \\
\text { to vasectomy }\end{array}$ & & & & & & & $\square$ \\
\hline
\end{tabular}

Five countries (Bolivia, Dominican Republic, Ecuador, El Salvador, Guatemala, Honduras, and Nicaragua) mentioned that they would implement the BCS and/or systematic screening. Concrete follow-up actions included:

\section{Bolivia:}

a) Sharing workshop lessons with national and institutional authorities.

b) Develop action plans.

c) Promote the exchange of experiences between institutions and countries.

\section{Dominican Republic:}

a) UNFPA and the Social Security Institute will call for a joint meeting to share the workshop results with national and institutional authorities.

b) Take the lead on creating a forum to exchange experiences among workshop participants to create new alliances between institutions and cooperation agencies. 


\section{Ecuador:}

a) Train family planning counselors in the BCS.

b) Train family planning counselors to promote postpartum minilaparotomy and vasectomy.

c) Train more staff to strengthen postabortion family planning.

\section{El Salvador:}

a) Share the lessons learned with the national contraceptive security committee and professional associations.

b) Adapt and implement the BCS for the $\mathrm{MOH}$, Social Security Institute and NGOs.

c) Adapt and implement systematic screening in the $\mathrm{MOH}$.

d) Continue IUD, no-scalpel vasectomy and minilaparotomy training in the $\mathrm{MOH}$ and the Social Security Institute.

e) Start actions to integrate family planning and PMTCT.

\section{Guatemala:}

a) Strengthen family planning counseling in all sectors.

b) Strengthen the implementation of systematic screening and BCS.

\section{Honduras:}

a) Share the materials and results of the BCS and systematic screening with $\mathrm{MOH}$ authorities.

b) Discuss the implementation of the BCS and systematic screening with the family planning and HIV/AIDS directors in the $\mathrm{MOH}$.

c) Develop an action plan.

\section{Nicaragua:}

a) Share the materials and results of the workshop with national authorities.

b) Organize talks in hospitals and health clinics to sensitize health staff about the need to integrate family planning and other services.

c) Monitor the implementation of existing interventions.

d) Strengthen the PMTCT program. 


\section{APPENDIX 1: FRONTIERS PROJECTS REFERRED TO DURING THE WORKSHOP, BY COUNTRY OF IMPLEMENTATION}

\begin{tabular}{|c|c|}
\hline Country & Project \\
\hline Bolivia & $\begin{array}{l}\text { Operations research to improve postabortion care (PAC) services in three } \\
\text { hospitals in Bolivia }\end{array}$ \\
\hline Bolivia & Technical assistance and training for PROCOSI's OR program \\
\hline Bolivia & Technical assistance to Pathfinder on operations research \\
\hline Bolivia & $\begin{array}{l}\text { Testing a model for the delivery of emergency obstetric care and family } \\
\text { planning services in the Bolivian public health system }\end{array}$ \\
\hline Bolivia & Use of systematic screening to provide reproductive health services \\
\hline $\begin{array}{l}\text { Dominican } \\
\text { Republic }\end{array}$ & $\begin{array}{l}\text { Contraceptive services in postpartum, postabortion and PMTCT Programs, } \\
\text { Dominican Republic }\end{array}$ \\
\hline Guatemala & Availability and acceptability of IUDs in Guatemala \\
\hline Guatemala & $\begin{array}{l}\text { Improving client informed choice, continuation in family planning, } \\
\text { method-mix, and cost-effectiveness at the postpartum/postabortion clinic } \\
\text { of the Gineco-Obstetrics Hospital, IGSS }\end{array}$ \\
\hline Guatemala & $\begin{array}{l}\text { Increasing access to long-term contraceptives (IUDs) in rural areas } \\
\text { through the MOH in Guatemala }\end{array}$ \\
\hline Guatemala & Expanding access to vasectomy services in Guatemala \\
\hline Guatemala & Reproductive health care in the postpartum period \\
\hline Guatemala & Scaling-up a successful counseling model: Guatemala \\
\hline Guatemala & $\begin{array}{l}\text { Testing a three-phase counseling algorithm with relating job aids and } \\
\text { supervision to improve the quality of family planning care in health } \\
\text { centers and posts of the Guatemalan MSPAS }\end{array}$ \\
\hline Haiti & $\begin{array}{l}\text { Situation analysis of the use of contraception in postpartum, postabortion } \\
\text { and prevention of mother-to-child HIV transmission }\end{array}$ \\
\hline Honduras & Disseminating information on the IUD in rural Honduras \\
\hline Honduras & Expansion of postpartum and postabortion contraception \\
\hline Honduras & $\begin{array}{l}\text { Expansion of the role of nurse auxiliaries in the provision of family } \\
\text { planning services phase } 1\end{array}$ \\
\hline Honduras & $\begin{array}{l}\text { Expansion of the role of nurse auxiliaries in the provision of family } \\
\text { planning services phase } 2\end{array}$ \\
\hline Honduras & $\begin{array}{l}\text { Systematic screening as a strategy to increase services integration and } \\
\text { revenue }\end{array}$ \\
\hline India & Systematic screening for integrating reproductive health services in India \\
\hline Nicaragua & $\begin{array}{l}\text { Situational Analysis of the Use of Contraception in Postpartum, } \\
\text { Postabortion and PMTCT Programs, Nicaragua }\end{array}$ \\
\hline Peru & $\begin{array}{l}\text { Provider and client impacts of an intervention designed to improve the } \\
\text { provider-client interaction in MOH clinics in Peru }\end{array}$ \\
\hline enegal & $\begin{array}{l}\text { Using systematic screening to enhance integration of reproductive health } \\
\text { service delivery in Senegal }\end{array}$ \\
\hline
\end{tabular}




\section{APPENDIX 2: WORKSHOP AGENDA}

\begin{tabular}{|c|c|c|}
\hline \multicolumn{3}{|c|}{ Monday, October 8, 2007} \\
\hline 19:30-21:30 & \multicolumn{2}{|l|}{ Welcome dinner } \\
\hline \multicolumn{3}{|c|}{ Tuesday, October 9, 2007} \\
\hline 07:00 - 8:00 & \multicolumn{2}{|l|}{ Breakfast } \\
\hline $08: 00-8: 45$ & \multicolumn{2}{|l|}{ Registration } \\
\hline 09:00 - 09:30 & $\begin{array}{l}\text { Inauguration and presentation of distinguished } \\
\text { participants: } \\
\text { Pierre Mercier, USAID/Haiti } \\
\text { John Townsend, Population Council/New York }\end{array}$ & $\begin{array}{l}\text { Moderator: } \\
\text { Alejandro Silva, } \\
\text { MSPAS/Guatemala }\end{array}$ \\
\hline 09:30 - 10:00 & $\begin{array}{l}\text { Current situation of Family Planning programs in Latin } \\
\text { America and the Caribbean }\end{array}$ & $\begin{array}{l}\text { John Townsend, } \\
\text { Population Council/NY }\end{array}$ \\
\hline $10: 00-10: 15$ & \multicolumn{2}{|l|}{ Coffee break } \\
\hline $10: 15-10: 30$ & Workshop objectives & $\begin{array}{l}\text { Estela Rivero, Population } \\
\text { Council/Mexico }\end{array}$ \\
\hline $\begin{array}{l}10: 30-11: 15 \\
11: 15-11: 30\end{array}$ & $\begin{array}{l}\text { Contraceptive technology update: The IUD and the } \\
\text { IUS } \\
\text { Questions and answers }\end{array}$ & $\begin{array}{l}\text { Carlos Morales, } \\
\text { MSPAS/Guatemala } \\
\text { John Townsend, } \\
\text { Population Council/NY }\end{array}$ \\
\hline $11: 30-12: 00$ & Expanding access to the IUD in Guatemala & $\begin{array}{l}\text { Edwin Montúfar, } \\
\text { MSPAS/Guatemala }\end{array}$ \\
\hline $12: 00-12: 15$ & $\begin{array}{l}\text { The experience of a successful nurse in the IUD } \\
\text { program in the MOH in Guatemala }\end{array}$ & $\begin{array}{l}\text { Josefina Ajpop and Carlos } \\
\text { Fernando Alvarado, } \\
\text { MSPAS/Guatemala }\end{array}$ \\
\hline $12: 15-12: 45$ & Expanding access to the IUD in Honduras & $\begin{array}{l}\text { Alba L. Sánchez, } \\
\text { EngenderHealth/Honduras }\end{array}$ \\
\hline $12: 45-13: 15$ & $\begin{array}{l}\text { Eligibility checklists for IUD clients, discard } \\
\text { pregnancy and other job aids }\end{array}$ & $\begin{array}{l}\text { Edwin Montúfar, } \\
\text { MSPAS/Guatemala }\end{array}$ \\
\hline $13: 15-14: 15$ & \multicolumn{2}{|l|}{ Lunch } \\
\hline
\end{tabular}




\begin{tabular}{|c|c|c|}
\hline $\begin{array}{l}14: 15-14: 45 \\
14: 45-15: 00\end{array}$ & $\begin{array}{l}\text { Contraceptive technology update: Vasectomy } \\
\text { Questions and answers }\end{array}$ & $\begin{array}{l}\text { Salvador Estévez, } \\
\text { Secretaría de Salud/Mexico }\end{array}$ \\
\hline $15: 00-15: 30$ & $\begin{array}{l}\text { Results of the use of a systematic model to introduce } \\
\text { no-scalpel vasectomy in hospitals and maternity wards } \\
\text { in Guatemala }\end{array}$ & $\begin{array}{l}\text { Jorge Solórzano, } \\
\text { PNUD/Guatemala }\end{array}$ \\
\hline $15: 30-16: 00$ & $\begin{array}{l}\text { The experience of a successful surgeon in the } \\
\text { vasectomy program in the } \mathrm{MOH} \text { of Guatemala }\end{array}$ & $\begin{array}{l}\text { Otto René Alvarado, } \\
\text { MSPAS/Guatemala }\end{array}$ \\
\hline $16: 00-17: 30$ & \multicolumn{2}{|l|}{ Coffee break } \\
\hline $16: 15-17: 30$ & $\begin{array}{l}\text { Recap: } \\
\text { Identification of the most important lessons of the day } \\
\text { and written feedback }\end{array}$ & $\begin{array}{l}\text { Moderators: } \\
\text { Estela Rivero, Population } \\
\text { Council/Mexico } \\
\text { Salvador Estévez, } \\
\text { Secretaría de Salud/ } \\
\text { Mexico }\end{array}$ \\
\hline \multicolumn{3}{|c|}{ Wednesday, October 10, 2007} \\
\hline $7: 30-8: 45$ & \multicolumn{2}{|l|}{ Breakfast } \\
\hline $9: 00-10: 30$ & $\begin{array}{l}\text { Contraceptive technology update: Postpartum } \\
\text { minilaparotomy, standard days method and emergency } \\
\text { contraception }\end{array}$ & $\begin{array}{l}\text { Moderator: } \\
\text { Deborah Billings, Ipas/NC } \\
\text { José Manuel Espinal, } \\
\text { Secretaría de Salud/ } \\
\text { Honduras } \\
\text { Lidia de Mazariegos, } \\
\text { APROVIME/Guatemala } \\
\text { Daniel Aspilcueta, } \\
\text { INPPARES/Perú }\end{array}$ \\
\hline $10: 30-11: 00$ & \multicolumn{2}{|l|}{ Coffee break } \\
\hline $\begin{array}{l}11: 00-11: 45 \\
11: 45-12: 00\end{array}$ & $\begin{array}{l}\text { Postabortion contraception: Review of OR results in } \\
\text { LAC } \\
\text { Questions and answers }\end{array}$ & Deborah Billings, Ipas/NC \\
\hline $\begin{array}{l}12: 00-13: 00 \\
13: 00-13: 15\end{array}$ & $\begin{array}{l}\text { OR on postpartum contraception in LAC: A review of } \\
\text { results } \\
\text { Questions and answers }\end{array}$ & $\begin{array}{l}\text { Ricardo Vernon, } \\
\text { Population Council/Mexico }\end{array}$ \\
\hline
\end{tabular}




\begin{tabular}{|c|c|c|}
\hline $13: 15-14: 30$ & \multicolumn{2}{|l|}{ Lunch } \\
\hline $\begin{array}{l}14: 30-15: 45 \\
15: 45-16: 00\end{array}$ & $\begin{array}{l}\text { Integration of contraception services in PMTCT } \\
\text { programs } \\
\text { Questions and answers }\end{array}$ & $\begin{array}{l}\text { Estela Rivero, Population } \\
\text { Council/Mexico } \\
\text { Osvaldo Lorenzo, } \\
\text { SESPAS/Dominican Rep. } \\
\text { Yolani Valle, Secretaría de } \\
\text { Salud/Honduras }\end{array}$ \\
\hline $16: 00-16: 30$ & \multicolumn{2}{|l|}{ Coffee break } \\
\hline $16: 30-17: 30$ & $\begin{array}{l}\text { Recap: } \\
\text { Current situation and areas to prioritize in the } \\
\text { integration of family planning and postabortion, } \\
\text { postpartum and PMTCT services; and written feedback }\end{array}$ & $\begin{array}{l}\text { Moderator: } \\
\text { Estela Rivero, Population } \\
\text { Council/Mexico }\end{array}$ \\
\hline \multicolumn{3}{|c|}{ Thursday, October 11, 2007} \\
\hline $7: 30-8: 00$ & Breakfast & \\
\hline $\begin{array}{l}8: 00-8: 45 \\
8: 45-9: 00\end{array}$ & $\begin{array}{l}\text { Systematic Screening: Evidence of its effects from } \\
\text { OR } \\
\text { Questions and answers }\end{array}$ & $\begin{array}{l}\text { Ricardo Vernon, } \\
\text { Population Council/Mexico }\end{array}$ \\
\hline $9: 00-9: 30$ & $\begin{array}{l}\text { Quality of care: The Balanced Counseling Strategy } \\
\text { (BCS) and its effects }\end{array}$ & $\begin{array}{l}\text { Toni Martin, Population } \\
\text { Council/Mexico }\end{array}$ \\
\hline 9:30 - 10:00 & Expanding the use of the BCS in Guatemala & $\begin{array}{l}\text { Rossana Cifuentes, } \\
\text { AGMM/Guatemala }\end{array}$ \\
\hline 10:00-10:15 & Questions and answers & \\
\hline $10: 15-10: 30$ & \multicolumn{2}{|l|}{ Coffee break } \\
\hline $10: 30-12: 30$ & $\begin{array}{l}\text { Simultaneous mini-workshops on systematic screening } \\
\text { and BCS } \\
\text { Mini-workshop on systematic screening: A tool to help } \\
\text { integrate family planning and other reproductive health } \\
\text { services } \\
\text { Mini-workshop on BCS: Improving counseling on } \\
\text { contraceptive methods }\end{array}$ & $\begin{array}{l}\text { Patricia Riveros, } \\
\text { Population Council/Bolivia } \\
\text { Toni Martin, Population } \\
\text { Council/Mexico }\end{array}$ \\
\hline
\end{tabular}




\begin{tabular}{|c|c|c|}
\hline $12: 30-13: 00$ & Country-working groups: Planning for the future & \multirow{3}{*}{$\begin{array}{l}\text { Moderator: } \\
\text { Estela Rivero, Population } \\
\text { Council/Mexico }\end{array}$} \\
\hline $13: 00-13: 30$ & Country-working groups presentations and conclusions & \\
\hline $13: 30-13: 45$ & Workshop evaluation: Written feedback & \\
\hline $13: 45-14: 00$ & Workshop closure & $\begin{array}{l}\text { Ricardo Vernon, } \\
\text { Population Council/Mexico }\end{array}$ \\
\hline $14: 00-15: 00$ & \multicolumn{2}{|l|}{ Lunch } \\
\hline $15: 00-19: 30$ & \multicolumn{2}{|l|}{ Free afternoon } \\
\hline $19: 30-22: 30$ & $\begin{array}{l}\text { Dinner to present the book: Billings, Deborah, Ricardo } \\
\text { Vernon, (Eds). } 2007 \text { "Avances en la atención posaborto } \\
\text { en América Latina y el Caribe: Investigando, aplicando } \\
\text { y aprendiendo [Advances in Postabortion Care in Latin } \\
\text { America and the Caribbean: Research, Implementation } \\
\text { and Scaling-up]." Mexico, D.F.: Ipas, Population } \\
\text { Council. }\end{array}$ & $\begin{array}{l}\text { Presentors: } \\
\text { Nadine Gasman, UNFPA/ } \\
\text { Guatemala } \\
\text { Gustavo Gutiérrez, } \\
\text { Independent practice/ } \\
\text { Guatemala } \\
\text { Deborah Billings, } \\
\text { IPAS/NC } \\
\text { Ricardo Vernon, } \\
\text { Population Council/Mexico }\end{array}$ \\
\hline
\end{tabular}




\section{APPENDIX 3. LIST OF PARTICIPANTS}

\section{Bolivia}

Dr. José Luis Alfaro

Technical Manager

Centro de Investigación, Estudios y

Servicios (CIES)

Dra. Carmen Estepa

Manager of Mobile Health Units and

Services

Centro de Investigación, Estudios y

Servicios (CIES)

Dr. Julio César Koca

Health Services Planning Manager

Ministerio de Salud y Deportes

Lic. Patricia Riveros

Consultant

The Population Council

\section{Dominican Republic}

Dra. Ana Delia Figueroa

Clinical Services Manager

Secretaria de Estado de Salud Pública y

Asistencia Social (SESPAS)

Dr. Osvaldo A. Lorenzo

Manager of the National Program to

Reduce the Vertical Transmision of HIV

Dirección General de Control de las ITS y

SIDA (DIGECITSS)

Secretaria de Estado de Salud Pública y

Asistencia Social (SESPAS)

Dra. Luz A. Mercedes

Medical Coordinator

United Nations Population Fund (UNFPA)

Dra. Clavel Sánchez

Reproductive Health Manager
Instituto Dominicano de Seguros Sociales (IDSS)

Dra. Clara I. Santillan

Technical Coordinator

Asociación Dominicana Pro-Bienestar de

la Familia (PROFAMILIA)

Dra. Nury M. Vargas

Medical Provider

Asociación Dominicana Pro-Bienestar de la Familia (PROFAMILIA)

Dra. Rumalda A. Vázquez

Medical Provider

Asociación Dominicana Pro-Bienestar de la Familia (PROFAMILIA)

\section{Ecuador}

Dra. Magda C. Acosta

Physician

Centro Médico de Orientación y

Planificación Familiar (CEMOPLAF)

Dra. Tula L. Verdezoto

Guaranda, Bolívar Medical Center

Director

Centro Médico de Orientación y

Planificación Familiar (CEMOPLAF)

\section{EI Salvador}

Ing. Rafael A. Avendaño

Executive Director

Asociación Demográfica Salvadoreña (ADS)

Lic. Claudia Lara

Nurse, Integral Care for Women Program Instituto Salvadoreño del Seguro Social (ISSS) 
Dra. L. Esmeralda Ramirez

National Coordinator of the Family

Planning Program

Ministerio de Salud y Asistencia Social

(MSPAS)

Dr. Mario A. Morales

Reproductive Health Officer

United Nations Population Fund (UNFPA)

Dr. Carlos A. Morales

Local Coordinator, Integral Care for

Women Program

Instituto Salvadoreño del Seguro Social

(ISSS)

Dra. Irma Georgina Santamaría

Coordinator, Integral Care for Women

Program

Instituto Salvadoreño del Seguro Social (ISSS)

\section{Guatemala}

Lic. Josefina Ajpop

Registered Nurse

Patzicia Health Center

Ministerio de Salud Pública y Asistencia

Social (MSPAS)

Lic. Otto René Alvarado

"Maternidad Primero de Julio" Hospital

Director

Ministerio de Salud Pública y Asistencia

Social (MSPAS)

Lic. Carlos Fernando Alvarado

IEC Coordinator

Patzicia Health Center

Ministerio de Salud Pública y Asistencia

Social (MSPAS)

Dra. Sandra Barahona

Physisian

Alianzas/USAID
Dr. Rodrigo Barillas

Health Cooridinator

Alianzas/USAID

Lic. Carlos Bauer

Executive Director

Asociación Pro Bienestar de la Familia de

Guatemala (APROFAM)

Dra. Rossana Cifuentes

President

Asociación Guatemalteca de Mujeres

Médicas (AGMM)

Nadine Gasman

Representative in Guatemala

United Nations Population Fund (UNFPA)

Dr. Gustavo Gutiérrez

Gynecologist

Independent practice

Lic. Lidia A. de Mazariegos

Director

Asociacion Pro Salud Preventiva para la

Mujer Vivamos Mejor (APROVIME)

Dr. Edwin Montúfar

Reproductive Health Technical Advisor

Ministerio de Salud Pública y Asistencia

Social (MSPAS)

Dr. Carlos René Morales

Family Planning Advisor of the National

Reproductive Health Program

Ministerio de Salud Pública y Asistencia

Social (MSPAS)

Dr. Edwin Morales

Medical Services Manager

Asociación Pro Bienestar de la Familia de Guatemala (APROFAM)

Lic. Blanca E. Rodríguez

Consultant 
United Nations Develpoment Programme (UNDP)

Dr. Alejandro Silva

Coordinator of the National Reproductive Health Program

Ministerio de Salud Pública y Asistencia Social (MSPAS)

Dr. Jorge Solórzano

UEP Director

United Nations Develpoment Programme (UNDP)

Dra. Berta Taracena

Consultant

Proyectos, Consultorías y Desarrollo (PROCONDE)

\section{Haiti}

Florence D. Guillaume MD

Deputy Chief of Party/Technical Director

Management Sciences for Health (MSH)

Dr. Lucito Jeannis

Haiti Representative

JHPIEGO

Pierre Mercier, MD MPH

Senior Medical Advisor/

Development Assistance Specialist

United States Agency for International

Development (USAID)

\section{Honduras}

Lic. Élida R. Aguilar

Nurse, National Integral Care for Women

Program

Secretaría de Salud

Dr. Manuel E. Carrasco

Chief of the Care for Men Program

Secretaría de Salud
Dr. Jose Manuel Espinal

Chief of Emergency Care, Maternal and

Child Hospital

Secretaría de Salud

Dra. Flor M. Matute

Manager of the Reproducitve Health

Subprogram

Fondo de Población de las Naciones

Unidas (UNFPA)

Lic. Alba Lidia Sánchez

Honduras Country Director

EngenderHealth

Dr. Manuel A. Sandoval

Medical Director

ASHONPLAFA

Lic. Yolany C. Valle

Departamental Coordinator of the

Prevention of Mother to Child

Transmision of HIV Program

Secretaría de Salud

\section{Mexico}

Dr. Salvador Estévez

National Trainer and Certifyer of the

Vasectomy Program

Centro Nacional de Equidad de Género y

Salud Reproducitva

Secretaría de Salud

Lic. Antonieta Martin

FRONTIERS LAC Communications

Officer

The Population Council

Susana Medina

FRONTIERS Administrative Assistant

The Population Council

Dra. Estela Rivero

FRONTIERS LAC Program Associate

The Population Council 
Dr. Ricardo Vernon

FRONTIERS LAC Associate Director

The Population Council

\section{Nicaragua}

Dra. Dinorah Corea

Service Organization Coordinator

Ministerio de Salud

Dr. Alejandro Ortiz

Medical Care Coordinator

Ministerio de Salud

Dra. Sonia M. Picado

Physician

\section{Peru}

Dr. Daniel Aspilcueta

Executive Director

Instituto Peruano de Paternidad

Responsable (INPPARES)

\section{United States}

Deborah L. Billings, PhD

Senior Associate, Research and Evaluation Ipas

John W. Townsend, Ph.D.

Reproductive Health Program Director

The Population Council
Dra. M. Fabiola González

Quality and Monitoring Manager

Centro de Mujeres Ixchen

Dr. Luis Alfredo Ortega

Sexual and Reproducitve Health Specialist

Nicasalud - Famisalud/USAID

Pro Mujer Nicaragua

Dr. Luis Manuel Urbina

Safe Motherhood Advisor

Healthcare Improvement Project/USAID 


\title{
APPENDIX 4: FEEDBACK QUESTIONNAIRES AND WORKING GROUP GUIDELINES
}

\author{
Feedback questionnaire \\ Tuesday, October 9, 2007 and \\ Wednesday, October 10, 2007
}

Please answer to the following questions before leaving the meeting room for the rest of the afternoon. This should not take you more than three minutes.

1. Which of the topics discussed today was most interesting or useful for your work?

2. Summarize, in one phrase, a message or lesson that you learned today

3. Do you have any suggestion to increase the impact of the lessons and experiences discussed today on your country or organization?

Thank you very much and we'll see you tomorrow! 


\section{Final feedback questionnaire Thursday, October 11, 2007}

This questionnaire will help us know your general opinion about the workshop, and to know what we can do to improve our future workshops and attempts to share our experiences.

Answering the following questions may take you more than 5 minutes, but your answers will be very helpful to us.

1. In general, would you say that the workshop was very useful, somewhat useful, or not useful at all for your work?

2. What did you like the most about the workshop?

3. What did you like the least?

4. Would you say that the experiences and lessons discussed are useful for improving family planning services in your country or organization?

5. Of the topics and experiences discussed, is there one that is particularly relevant for your country or organization?

6. Do you plan to do something to share the workshop lessons once you go back to your country? What do you plan to do?

\section{Thank you!}




\title{
Guide 1
}

Guide for working groups 1: Identification of the day's most important lessons and of the interventions that can be useful in your program

\author{
Tuesday, October 9, 2007
}

Note: Instructions for dividing into groups and group dynamics are omitted as in the end, participants were asked to write an answer to the guiding questions individually.

During this exercise, each group should identify:

- Which concrete actions can be taken to increase access to the IUD in their country or organization

- Which obstacles may exist for these actions

- Which concrete actions can be taken to increase access to no-scalpel vasectomy in hospitals and maternity wards

- Which obstacles may exist for these actions 


\title{
Guide 2
}

Guide for working groups 2: Current situation and recommendations to improve the integration of family planning and postpartum, postabortion and PMTCT services

\author{
Wednesday, October 10
}

Note: Instructions for dividing into groups and group dynamics are omitted as in the end, participants were asked to write an answer to the guiding questions individually.

Participants will discuss the following issues:

- How integrated are family planning services with postabortion, postpartum and PMTCT services in your country or organization?

- What should be the priority in these integration efforts?

- Which of the integration strategies discussed today would be feasible in your organization?

- Which would be the obstacles to these strategies? 


\section{Guide 3}

\section{Guide for working groups 3: Planning for the future}

Thursday, October 11, 2007

This last session has the goal of allowing participants from the same country to discuss whether and how the lessons and topics discussed during the workshop may be of use to them, and to propose concrete actions for their implementation.

Participants from the same country should get together and form a working group. Each group will have a special place to work, with a blackboard and markers to support their work. Each group has an hour to identify:

- Which of the topics and lessons discussed during the program is of most use for their program

- $\quad$ Three concrete actions to put the lessons learned into practice that they will take when they go back to their country

We will gather again in the meeting room at 15:45. At that time, each group will present, in 5 minutes, the lessons that they identified as a priority and their action plans. 